\title{
Managing the transition decades: Tactical options for an uncertain route towards a clear strategic goal
}

DOI:

10.1016/j.cherd.2009.08.001

Link to publication record in Manchester Research Explorer

\section{Citation for published version (APA):}

Campbell, G. M., Azapagic, A., \& Vadlani, P. (2009). Managing the transition decades: Tactical options for an uncertain route towards a clear strategic goal. Chemical Engineering Research and Design, 87(9), 1101-1102. https://doi.org/10.1016/j.cherd.2009.08.001

\section{Published in:}

Chemical Engineering Research and Design

\section{Citing this paper}

Please note that where the full-text provided on Manchester Research Explorer is the Author Accepted Manuscript or Proof version this may differ from the final Published version. If citing, it is advised that you check and use the publisher's definitive version.

\section{General rights}

Copyright and moral rights for the publications made accessible in the Research Explorer are retained by the authors and/or other copyright owners and it is a condition of accessing publications that users recognise and abide by the legal requirements associated with these rights.

\section{Takedown policy}

If you believe that this document breaches copyright please refer to the University of Manchester's Takedown Procedures [http://man.ac.uk/04Y6Bo] or contact uml.scholarlycommunications@manchester.ac.uk providing relevant details, so we can investigate your claim.

\section{OPEN ACCESS}




\section{Editorial}

\section{Managing the transition decades: Tactical options for an uncertain route towards a clear strategic goal}

\begin{abstract}
"Like baseball's immortal Tinkers to Evers to Chance, the future of energy is starting to look like it could be crude oil to biofuel to electricity." Bill Paul (2007) "Future Energy: How the New Oil Industry will change People, Politics and Portfolios", p. 113.

We are in the transition decades. The increasingly urgent consensus over the twin issues of oil depletion and climate change has obliged a sudden and rapid stampede towards renewable sources of energy and materials. The luxury of time to gather information, to undertake research, to ponder carefully and debate fully, to train and educate, and to create new political, industrial and social paradigms has not been available. Decisions have been made, leading to progress and to mistakes, and much has been learnt - but we're not there yet.

Within the storm of vested interests, stark realities and "inconvenient truths", biorefineries have occupied an unenviably ambiguous position. Hailed initially as a valuable contributor to alleviating oil depletion and climate change while enhancing rural economies along with national security and independence, by 2007 biofuels were denounced by UN spokesman Jean Ziegler as "a crime against humanity" due to their current reliance on food crops. The great white hope is therefore lignocellulosic-based biorefineries, which promise abundant and cheap feedstocks without adverse consequences for global food supplies. But it is practically a cliché that commercially viable processing of lignocellulosics to ethanol is always 5 years away - again, we're not there yet. Alternatively, cars powered by electricity from renewables are seen as a way of circumventing the liquid biofuel problem. Identifying and describing these future scenarios in which difficult conflicts have been overcome is relatively simple. Getting from here to there is the real and immediate challenge requiring tactical decisions in the face of uncertainty. But it is certain that the path from here to there runs, one way or another, through biorefineries.
\end{abstract}

In establishing the basis for sustainable energy and chemicals production through commercially viable biorefineries, the competition is clearly oil. Oil refineries benefit from a cheap and easily converted feedstock, along with advanced technologies, vast and diverse markets, and well established infrastructures. Less conspicuously, oil refining also benefits from extensive process integration, in which heat and process streams are recovered and reused to give outstanding energetic and economic efficiencies. In competing with oil, and in delivering their maximum potential in relation to energy and environmental benefits, emergent biorefineries must adopt and adapt the process integration approaches that currently advantage oil refineries. Biorefineries are behind oil with respect to developing and applying process integration by several decades. There is much that can be learned and transferred, but there are also issues that are prominent in biorefining but as yet inadequately addressed by existing process integration tools.

It is this recognition of the need for process integration to be developed specifically for biorefineries, and deployed to facilitate their introduction and to maximise their benefits, that was the motivation for the current special topic issue on "Biorefinery Integration". But there is an additional nuance that also underpinned the motivation for this special issue. Like oil refineries, biorefineries must develop and apply integration within their processes. But biorefineries must also be integrated externally with the rest of society, in ways that are arguably more subtle, complex and conspicuous that the integration of oil refining into society. Thus the call for papers for this special issue specifically requested contributions that addressed both the internal and the externally facing aspects of Biorefinery Integration, noting: "The impacts of biorefining are in many ways more apparent and acute than the more hidden and indirect impacts of the chemical and energy industries that quietly served our needs in the 20th century. This is most evident in the "food versus fuel" debate, in which the impacts of growing crops for fuel in competition with food crops are felt, understood and acted on (or reacted against) directly by society. There are also less obvious but equally relevant and complex interactions that need to be understood in order to inform policymakers and industrial practice; for example, the effects on energy and emissions of displacement of one type of animal feed with another as a result of biorefinery activities. However, these interactions are complex and subtle, requiring comprehensive life cycle analysis based on appropriate data and information. Thus this special issue on the subject of Biorefinery Integration calls for two types of paper. First, those dealing with the application of process integration principles to biorefineries, in order to enhance their energy efficiency and economic competitiveness and thereby to facilitate their appropriate introduction. And secondly, those looking at how biorefineries interact with agriculture, the food industry and the wider societal and policy frameworks and initiatives addressing sustainability and climate change, in order to integrate biorefineries most helpfully with the rest of 21st century activity and development." 
The call for papers was very successful, resulting in the selection appearing in this current issue, which demonstrate the scope and quality of work being carried out all over the world on these two aspects of Biorefinery Integration. It is thus our hope that these papers will contribute to communicating and consolidating progress and direction in these areas. However, the call also elicited a number of papers describing research that, although relevant to biorefining and of great interest to the community, did not specifically address the integration agenda of the special issue. The solution to this dilemma was to conceive a companion special topic issue in ChERD's sister journal, Food and Bioproducts Processing, entitled "Biorefinery Innovations". This unique "special topic pair" will together, we hope, provide a valuable collection of papers giving context and detail on these two complementary aspects of advances in biorefinery engineering, in order to help the transition "from here to there".

The evolving role of biorefineries will require decision making at many local, national and international levels. Decision making, in relation to really big decisions, assumes availability of Options, to which are applied Courage and Judgement. (At least, proactive and commendable decision making does. Decisions made by default through cowardice or neglect are still decisions, and still have consequences.) Chemical engineers are inclined to describe themselves as Problem Solvers. They perhaps aspire less to defining themselves as Decision Makers. But they have the skills to contribute to effective decision-making. In this they may serve as Option Providers, drawing on their unique combination of fundamental and pragmatic skills within a systems framework to create new ways of meeting society's material needs. Many of the papers in these two companion special issues illustrate the chemical engineer as a Creator of Options. Or they may draw on this same toolbox to evaluate alternatives and distinguish between plausible and optimal solutions; again, many of the papers presented here illustrate this power of Engineering Judgement. Chemical engineers clearly have limitations and blind spots, it must be acknowledged, but an intuition for integrated perspectives gives the chemical engineering community a unique contribution to offer. An ongoing challenge is to integrate the contributions of chemical engineers into courageous national and global decisions about how the next few transition decades, on which the future of humanity hinges, will be managed.

Grant M. Campbell ${ }^{a, *}$ Adisa Azapagic ${ }^{a}$ Praveen Vadlani ${ }^{b}$

a University of Manchester, School of Chemical Engineering and Analytical Science, PO Box 88, Manchester M60 1QD, United Kingdom

$\mathrm{b}$ Department of Grain Science \& Industry, 201 Shellenberger Hall, Manhattan, KS 66506, USA

* Corresponding author. E-mail address: grant.campbell@manchester.ac.uk (G.M. Campbell)

0263-8762/\$ - see front matter Crown Copyright (C) 2009 Published by Elsevier B.V. on behalf of The Institution of Chemical Engineers. All rights reserved. doi:10.1016/j.cherd.2009.08.001 